\title{
Effect of Good Corporate Governance, DER, Asset Growth Mechanism on Company Performance
}

\author{
Abdul Rahim ${ }^{1}$, Kartika Mirawati ${ }^{2}$, Juhasdi Susono ${ }^{3}$ \\ ${ }^{2}$ Universitas Negeri Jakarta, Jakarta, Indonesia \\ e-mail: kartika.mirawati@gmail.com \\ ${ }^{1,3}$ Institut Agama Islam Negeri (IAIN) Bone, South Sulawesi, Indonesia \\ e-mail: ${ }^{2}$ rahimilmi72@gmail.com; ${ }^{3}$ juhasdimm@gmail.com
}

\begin{abstract}
This study aims to determine the effect of the mechanism of Good Corporate Governance, DER, Asset Growth on company performance (empirical studies on mining companies listed on the Indonesia, Thailand, Malaysia Stock Exchange period 2010-2017). This research is quantitative research which aims to systematically explain about the facts and properties in an object in the study then merged between variables related to it by presenting secondary data from financial reports from mining companies in the countries of Indonesia, Malaysia,and Thailand. The samples used in this study were 15 mining companies in the countries of Indonesia, Malaysia, and Thailand. In this study, the data analysis method used is the data panel (pooled data) which is a combination of time series data and data between individuals or cross sections in mining companies in Indonesia, Malaysia, and Thailand. This research indicates that the variation of the profit company's performance can be explained by the independent variables analyzed.
\end{abstract}

Keywords-Good Corporate Governance; DER; Asset Growth; company performance

\section{INTRODUCTION}

Every company has an interest in measuring the performance of the company. Nowadays, the purpose of the company is only to generate maximum profit that is no longer relevant because the company's responsibility is not only to the owner[1]. Therefore, responsibility to all stakeholders becomes very important, so this requires the company to weigh all the strategies taken and their impact on these stakeholders. Therefore, the appropriate goal is to maximize the value of a company. Determining the right goals affects the process of achieving goals and performance measurement later[2]. The mistakes in setting goals result in a strategy error taken. Errors in performance measurement results in errors in rewarding real achievements. Good corporate governance is a process and structure for manufacturing companies to increase business success and corporate accountability in order to realize long-term shareholder value while taking into account the interests of other stakeholders based on laws and ethical values[3]. Stakeholders are parties who have interests with manufacturing companies, both directly and indirectly, namely shareholders/capital owners, commissioners / supervisory boards, directors and employees as well as the government, creditors, and other interested parties. 
The concept of Good Corporate Governance arises as an effort to break and overcome selfish management behavior by creating mechanisms and means of control to enable the creation of a balanced profit and wealth sharing system for stakeholders and create efficiency for the company.The good corporate governance system provides a structure that creates company objectives and equipment needed to achieve company goals, as well as a monitoring system for measuring performance[4]. So this system regulates clearly and explicitly what the rights and obligations of the parties related to the implementation of a business corporation such as the Board of Commissioners, Board of Directors, management, shareholders and other stakeholders.

In Indonesia, the implementation of good corporate governance has become an obligation for public companies listed on the Indonesia Stock Exchange (IDX)[5]. Along with the development of the concept of good corporate governance, the Indonesian Institute for Corporate Governance (IICG) as an independent institution conducts the activities of dissemination and development of good corporate governance in Indonesia. It conducts research and ratings on the implementation of good corporate governance in public companies and BUMN or known as the Corporate Governance Perception Index (CGPI).

The company's capital structure must maximize profit for the benefit of its capital, and the profits must be higher than the cost of capital as a result of the use of certain capital structures. Capital structure is complicated because it relates to other financial decision decisions[6].

The measurement of company performance and business units are grouped into three categories[7], namely: (1) Earning Measures, which based on performance in accounting profit. The calculations include earnings per share (EPS), return on investment (ROI), return on net assets (RONA), return on capital employed (ROCE) and return on equity (ROE), (2) Cash flow measures, which base performance on operating cash flow (operating cash flow)

The calculations include free cash flow, cash flow return on gross investment (ROGI), cash flow return on investment (CFROI), total shareholder return (TSR) and total business return (TBR), and (3) Value measures, which base performance on value (value based management). The calculations include economic value added (EVA), market value added (MVA), cash value added (CVA) and shareholder value (SHV).To complete the way of measuring company performance that has existed over the past few years an approach has been developed called Economic Value Added (EVA)[8]. The EVA is a management consulting company headquartered in New York, United States.

The EVA approach is considered more accurate and comprehensive compared to previous conventional approaches that do not describe the company's financial condition correctly[9]. EVA lets managers choose investments that maximize the rate of return and minimize the level of capital costs so that the value of the company can be maximized.EVA (Economic Value Added) is a value added by management to shareholders during a 
given year. EVA is a performance measurement that contains the total performance factors because it has included all elements in the profit/loss report and the company's balance sheet[10]. Economic Value Added is a measure of economic value added produced by the company as a result of the existence of management activities or strategies.

EVA tries to measure the added value produced by a company by reducing the cost of capital arising from the investments made. Positive EVA indicates that the company has succeeded in creating value for the owner of the company.This EVA concept can be a bridge that connects the management of the company owner because this concept stems from the concept of capital costs, namely the optimum risk, namely Debt to Equity Ratio (DER). The company strives to achieve a good DER so that it will try to reduce the cost of capital and will automatically improve performance based on the concept of Economic Value Added (EVA).

In contrast to previous researchers, in this study, good corporate governance was proxies through 3 (three) components, including the existence of audit committees, the board of commissioners, managerial ownership, capital structure, and asset growth. The more components used to proximate good corporate governance are expected to obtain research results that better represent the disclosure of good corporate governance.

The object of this study was conducted on mining sector companies listed on the Indonesia, Thailand and Malaysia Stock Exchanges because the mining sector is one of the business sectors that is closely related to the issue of social responsibility and years of research starting in 2010-2017, with more expected years to be found significant influence on company performance. Also, the number of companies in the mining sector is large enough so that motivation to obtain sufficient samples in research can be fulfilled.Researchers are motivated to conduct this research to test the consistency of the results of previous research that has been done regarding the effect of good corporate governance mechanisms on company performance in companies with the mining sector in several ASEAN countries (Indonesia, Thailand,and Malaysia).

\section{METHOD}

This research is quantitative research, so after all, data has been collected then the next will be done data analysis. In this study, the data analysis method used is panel data (pooled data) which is a combination of time-time data and data between individuals or spaces (cross-section). The data panel technique is a combination of cross-section data type and time series, describing the type of advantage of cross-section and time series standard approach[11], [12]. Data processing used in this research is Microsoft Excel, SPSS and Eviews. Data analysis method used in this research is multiple regression model. Data analysis method is used to explain the strength and direction of the influence of independent variables (independent variable) to the dependent variable (dependent variable). The method of analysis used is multiple linear regression model with the following formula: 


$$
Y=a+b_{1} X_{1}+b_{2} \cdot X_{2}+b_{3} X_{3} \cdot+b_{4}+e
$$

$$
\begin{array}{ll}
\mathrm{Y} & =\text { DER } \\
\mathrm{a} & =\text { Constant } \\
\mathrm{X}_{1} & =\mathrm{GRO} \\
\mathrm{X}_{2} & =\text { Committee } \\
\mathrm{X}_{3} & =\text { Stock } \\
\mathrm{X}_{4} & =\text { Commissioner } \\
\mathrm{b}_{1} & =\text { Coefficient regresion } \\
\mathrm{e} & =\text { error term }
\end{array}
$$

The value of the regression coefficient here is crucial as the basis of the analysis, considering that this research is a fundamental method. This means if the coefficient $b$ is positive $(+)$ then it can be said to have a direct influence between the independent variable with the dependent variable, each increase in the value of the independent variable will increase the dependent variable. Vice versa, if the coefficient of value $b$ is negative (-), it indicates a negative influence where the increase in the value of the independent variable will result in the decrease in the value of the dependent variable.

\section{RESULTS AND DISCUSSION}

\section{A. Analysis Unit Description}

In this study, data from 15 mining companies were taken from three stock exchanges in the countries of Indonesia, Malaysia,and Thailand. The selection of the three countries was made intentionally, namely the development of the three countries was better than other countries. In this study the variables used in this study are, Mechanism of Good Corporate Governance, Der, Asset Growth Has No Impact on Company Performance (Empirical Study of Mining Companies Registered on the Indonesia, Thailand, Malaysia Stock Exchange Period 2010-2017) and Descriptive Analysis Results the five variables are as follows:

TABLE I

VARIABLE DESCRIPTION FOR INDONESIA

\begin{tabular}{lrrrrrr}
\hline \hline & EVA & DER & GRO & Committee & Commissioner & Stock \\
\hline Average & 24.15 & 7.97 & 12.91 & 3.35 & 3.18 & 0.13 \\
Mean & 29.05 & 8.76 & 15.52 & 3.27 & 3.00 & 0.14 \\
Maximum & 43.90 & 17.05 & 23.46 & 5.12 & 4.00 & 0.25 \\
Minimum & -19.04 & -7.39 & -10.18 & 2.00 & 2.54 & 0.05 \\
Standard & 17.20 & 7.06 & 9.19 & 0.92 & 0.38 & 0.05 \\
Deviation & & & & & 12.09 & 38.63 \\
Coefficient & 71.21 & 88.55 & 71.21 & 27.41 & & \\
Variance & & & & &
\end{tabular}


Based on Table 1. shows that the company's performance (EVA) of mining companies in Indonesia is the variable with the most considerable variation compared to other variables. This can be seen from the highest coefficient of variation. Variables with changes that tend to be stable are the number of commissioners. A variable number of shares becomes a variable with high variation caused by mining companies that have entered the stock exchange so that ownership of the company can easily change ownership. The variable with the lowest variation in the number of commissioners. The number of commissioners tends to be stable because changes in the number of members tend to be consistent over time.

TABLE II

VARIABLE DESCRIPTION FOR MALAYSIA

\begin{tabular}{lrrrrrr}
\hline \hline & EVA & DER & GRO & \multicolumn{1}{l}{ Committee } & Commissioner & Stock \\
\hline Average & 34.62 & 10.08 & 17.83 & 4.15 & 4.14 & 0.19 \\
Mean & 41.95 & 11.35 & 22.16 & 4.00 & 4.00 & 0.20 \\
Maximum & 63.11 & 24.50 & 81.98 & 5.31 & 6.00 & 0.31 \\
Minimum & -28.56 & -7.39 & -20.69 & 2.00 & 2.66 & 0.07 \\
Standard & 24.79 & 9.79 & 18.86 & 0.91 & 1.06 & 0.07 \\
Deviation & 71.62 & 97.16 & 105.78 & 22.01 & 25.59 & 36.42 \\
Coefficient & $75 a r i a n c e$ & & & & & \\
\hline \hline
\end{tabular}

Based on Table 2. shows that the asset growth (gro) of mining companies in Malaysia is the variable with the most considerable variation compared to other variables. This can be seen from the highest coefficient of variation. Variables with changes that tend to be stable are the number of committee members. A variable number of shares becomes a variable with high variation caused by mining companies that have entered the stock exchange so that ownership of the company can easily change ownership. The variable with the lowest variation in the number of commissioners. The number of commissioners tends to be stable because changes in the number of members tend to be consistent over time

TABLE III

VARIABLE DESCRIPTIONFOR THAILAND

\begin{tabular}{lrrrrrr}
\hline \hline & EVA & DER & GRO & Committee & Commissioner & Stock \\
\hline Average & 40.86 & 16.35 & 21.36 & 4.59 & 4.56 & 0.25 \\
Mean & 49.73 & 18.67 & 25.20 & 5.00 & 5.00 & 0.24 \\
Maximum & 102.48 & 39.79 & 50.81 & 5.00 & 6.00 & 0.50 \\
Minimum & -49.98 & -18.42 & -24.78 & 2.75 & 3.00 & 0.09 \\
Standard & 36.72 & 12.42 & 18.77 & 0.72 & 1.01 & 0.09 \\
Deviation & & & & & &
\end{tabular}

IJoASER, Volume 1, Issue 2, July, 2018

DOI: 10.33648/ijoaser.v1i2.13

Copyright: STAI Al-Furqan Makassar, Indonesia

Content License: CC-BY-SA 
Based on Table 3 shows that the company's performance (EVA) of mining companies in Thailand is the variable with the most significant variation compared to other variables. This can be seen from the highest coefficient of variation. This is the same as that shown in descriptive statistics in Indonesia. Variables with changes that tend to be stable are the number of committee members. A variable number of shares becomes a variable with high variation caused by mining companies that have entered the stock exchange so that ownership of the company can easily change ownership. The variable with the lowest variation is the number of commissioners. The number of commissioners tends to be stable because changes in the number of members tend to be consistent over time.

\section{B. Test Model of the Panel Estimation Approach}

Analysis to see the factors that affect the profit performance of the company in countries in Indonesia, Malaysia and Thailand will be tested the selection of the best models. Model selection test was carried out with three (3) tests, namely the Chow test, Hausman test,and LM test. Chow test is done to choose between fixed effect models and common effects while the Hausman test is done to choose between random effects and fixed effects. LM test is done to choose between random effects and joint effects. The results of the analysis can be seen as follows

TABLEIV

ChOW TEST OF SOME COMPANIES IN INDONESIA, MALAysia, AND Thailand

\begin{tabular}{lrrrr}
\hline Country & Effects Test & Statistic & d.f. & Prob. \\
\hline Indonesia & Cross-section F & 0.737 & $(4.30)$ & 0.573 \\
& Cross-section Chi-square & 3.751 & 4 & 0.440 \\
Malaysia & Cross-section F & 1.773 & $(4.28)$ & 0.162 \\
& Cross-section Chi-square & 8.582 & 4 & 0.072 \\
Thailand & Cross-section F & 2.440 & $(4.30)$ & 0.068 \\
& Cross-section Chi-square & 11.268 & 4 & 0.023 \\
\hline
\end{tabular}

Based on Table 4. Chow tests showed similar results in Indonesia, Malaysia,and Thailand. This test similarity is seen from the test probability value (cross-section $\mathrm{F}$ ) which is above 5 percent (0.05). From the results of the Chow test, the selected estimation model is the joint effect. The Hausman test was not continued in this study because the selected estimation model was a common effect while the Hausman test was done to choose between random and fixed effects. Furthermore, the LM test was not continued because the characteristics of the data were balanced between the number of cross sections and the number of independent variables in this study.

1) Classic assumption test: Testing standard assumptions using panel data is not all used in the analysis. This is because the panel data is a combination 
of cross-section data (time latitude) and time series data (time series). In testing classic assumptions include autocorrelation, normality, heteroscedasticity,andmulticoinierity. Autocorrelation only occurs in time series data whereas heteroscedasticity usually occurs in cross-section data. For this reason, this analysis only tests classical assumptions, especially on multicollinearity and normality.

2) Multicollinearity test: Multicollinearity is a solid relationship between two independent variables. The implication is that a variable is formed based on other variables. Multicollinearity analysis of research is seen from the correlation or relationship between two independent variables. The characteristic of multicollinearity is the correlation coefficient value of more than 0.8 . For more details, see Table 5 as follows:

TABLE V

MULTICOLLINEARITYTESTS FOR VARIABLES IN INDONESIA

\begin{tabular}{lccrrr}
\hline Variable & DER & GRO & Committee & Commissioner & Stock \\
\hline DER & 1.00 & 0.79 & 0.16 & -0.06 & 0.27 \\
GRO & 0.79 & 1.00 & 0.37 & 0.27 & 0.12 \\
Committee & 0.16 & 0.37 & 1.00 & 0.36 & -0.16 \\
Commissioner & -0.06 & 0.27 & 0.36 & 1.00 & -0.07 \\
Stock & 0.27 & 0.12 & -0.16 & -0.07 & 1.00 \\
\hline
\end{tabular}

From Table 5, it can be seen that the correlation value between independent variables in mining companies in Indonesia is a capital structure (DER), asset growth (GRO), number of committee members, number of commissioners, and managerial ownership (shares) less than 0.8. This shows that there is no multicollinearity problem on these variables. Furthermore, the results of multicollinearity analysis on food companies in Malaysia can be seen in Table 6 below:

TABLE VI

MULTICOLLINEARITY TEST FOR INDEPENDENT VARIABLES IN MALAYSIA

\begin{tabular}{lcrrrr}
\hline Variable & DER & GRO & Committee & Commissioner & Stock \\
\hline DER & 1.00 & -0.02 & -0.23 & 0.46 & 0.17 \\
GRO & -0.02 & 1.00 & 0.36 & -0.09 & 0.35 \\
Committee & -0.23 & 0.36 & 1.00 & -0.38 & -0.05 \\
Commissioner & 0.46 & -0.09 & -0.38 & 1.00 & 0.29 \\
Stock & 0.17 & 0.35 & -0.05 & 0.29 & 1.00 \\
\hline
\end{tabular}

Based on Table 6. shows the correlation values between independent variables show the same results as in Indonesia. Correlation test shows the

IJoASER, Volume 1, Issue 2, July, 2018

DOI: 10.33648/ijoaser.v1i2.13

Copyright: STAI Al-Furqan Makassar, Indonesia

Content License: CC-BY-SA 
correlation value for each variable pair is less than 0.8 . Thus, for the case of food companies in Malaysia, there is no problem of multicollinearity.

TABLE VII

MULTICOLLINEARITYTESTS FOR INDEPENDENT VARIABLES IN THAILAND

\begin{tabular}{lcrrrr}
\hline Variable & DER & GRO & Committee & Commissioner & Stock \\
\hline DER & 1.00 & 0.78 & 0.39 & 0.06 & 0.55 \\
GRO & 0.78 & 1.00 & 0.50 & 0.15 & 0.65 \\
Committee & 0.39 & 0.50 & 1.00 & -0.21 & 0.18 \\
Commissioner & 0.06 & 0.15 & -0.21 & 1.00 & 0.49 \\
Stock & 0.55 & 0.65 & 0.18 & 0.49 & 1.00 \\
\hline
\end{tabular}

Based on Table 7. shows the correlation values for each pair of variables less than 0.8. Thus, for the case of food companies in Thailand, there is no problem of multicollinearity.

3) Normality test:Testing the next classic assumption is the problem of normality. This test is conducted to see the distribution of research data close to the sample average or not. If the research data spreads near the average, the data is said to be normal and vice versa. In the data distribution research was carried out by looking at the distribution of residuals (errors) of each sample. The data is said to be normal the probability value of the jarque probability is above 0.05 while if the jarque probability is below 0.05 then the data spread is not normal. The results of normality tests in Indonesia, Malaysia and Thailand can be seen in the graph below:

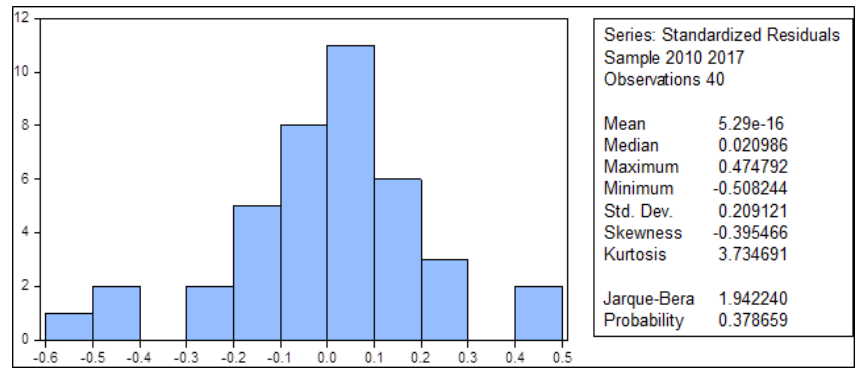

Fig. 1 Testing Normality in Indonesia

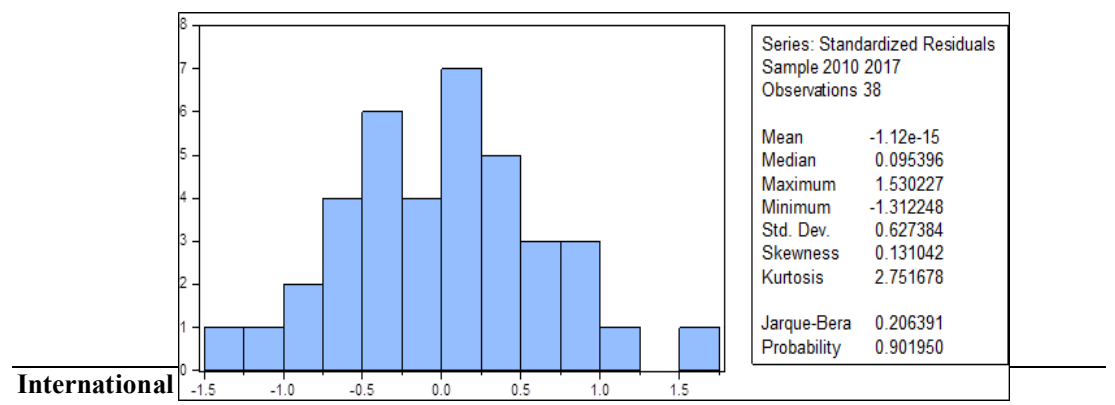


Fig. 2 Testing Normality in Malaysia

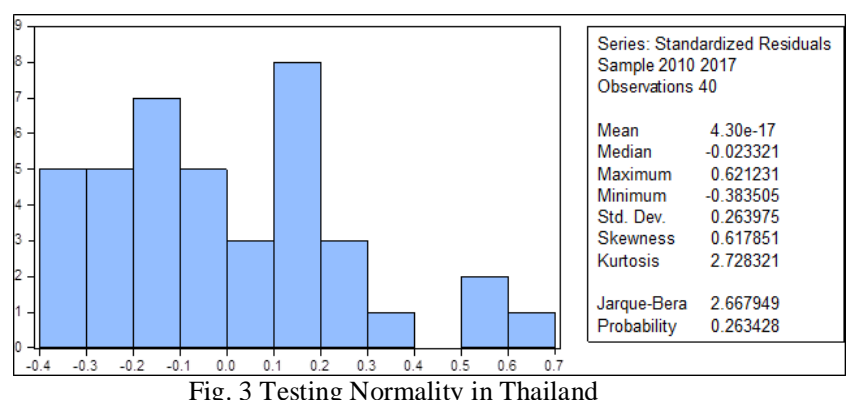

Based on Figure 1,2, and 3, they show that the Jarque-Bera probability value using residuals in Indonesia, Malaysia, and Thailand is above 5 percent (0.05). The probability value that is above 5 percent then the data used has spread commonly,or there is no problem of normality in this study.

4) Panel regression analysis:After getting the best model for each country, then continued with panel data regression analysis. Panel data analysis is a combination of time series and cross-section data. In the study, research variables both in Indonesia, Malaysia, and Thailand used the same estimation model which is a common effect. Here are the results of regression calculations using a statistical test tool Eviews 8.

5) Panel model regression analysis in Indonesia: The estimation results of the model of the effect of capital structure (DER), asset growth (GRO), managerial ownership (share), number of committees and commissioners with the typical effect estimation method in Indonesia can be seen in Table 8 below:

TABLE VIII

EstimATION RESUltS OF THE MODEL OF THE INFLUENCE OF DER, GRO, STOCKS ON THE PERFORMANCE OF COMPANIES IN INDONESIA

\begin{tabular}{lrrr}
\hline \hline Variable & Coefficient & Standard error & Probability \\
\hline Constant & 1.205 & 0.395 & 0.004 \\
DER & -0.068 & 0.084 & 0.418 \\
GRO & 0.351 & 0.073 & $0.000^{*}$ \\
Committee & 0.872 & 0.358 & $0.020^{*}$ \\
Commissioner & 0.227 & 0.151 & 0.143 \\
Stock & -0.024 & 0.062 & 0.698 \\
\hline R-square & & & 0.766 \\
Adjusted R-square & & & 0.732 \\
\hline
\end{tabular}

IJoASER, Volume 1, Issue 2, July, 2018

DOI: 10.33648/ijoaser.v1i2.13

Copyright: STAI Al-Furqan Makassar, Indonesia

Content License: CC-BY-SA 
Based on Table 8, it can be written the equation of the EVA dependent variable with the independent variable namely capital structure (DER), asset growth (GRO), number of committees, number of commissioners, and managerial ownership (shares) as follows:

$$
E V A=1.205-0.068+0.351+0.872+0.227-0.024+e
$$

Based on Table 8 it can be seen that together the independent variables included in this study affect the performance of mining companies in Indonesia. This can be seen from the F-statistical probability of 0,000 which is below the 0.05 value.

6) Panel model regression analysis in Malaysia.Estimation results of the model of the effect of capital structure (DER), asset growth (GRO), managerialownership (shares), number of committees and commissioners with the common effect estimation method in Malaysia can be seen in Table 9. below:

TABLE IX

ESTIMATION RESULTS OF THE MODEL OF THE INFLUENCE OF DER, GRO, SHARES ON THE PERFORMANCE OF COMPANIES IN MALAYSIA

\begin{tabular}{lrrr}
\hline \hline Variable & Coefficient & Standard error & Probability \\
\hline Constant & 4.139 & 1.388 & 0.005 \\
DER & 0.250 & 0.111 & $0.032^{*}$ \\
GRO & 0.448 & 0.097 & $0.000^{*}$ \\
Committee & 0.252 & 0.636 & 0.693 \\
Commissioner & 0.070 & 0.540 & 0.897 \\
Stock & 1.697 & 0.307 & $0.000^{*}$ \\
\hline R-square & & & 0.767 \\
Adjusted R-square & & & 0.731 \\
F-statistic & & & 21.165 \\
Prob (F-statistic) & & & 0.000 \\
\hline \hline
\end{tabular}

Based on Table 9, it can be written the equation of the EVA dependent variable with the independent variable namely capital structure (DER), asset growth (GRO), number of committees, number of commissioners, and managerial ownership (shares) as follows:

$$
E V A=4.139+0.250+0.448+0.52+0.070+1.697+e
$$


Based on Table 10 it can be seen that together the independent variables included in this study affect the performance of mining companies in Indonesia. This can be seen from the F-statistical probability of 0.000 . The value of Adjusted R Square of this model is 0.731 which means that the variation of the variables of the company's performance (EVA) which can be explained by the independent variables in the research is 73.10 percent, the remaining 26.90 percent is explained by other factors not included in this study. Adjusted $\mathrm{r}$ square value is excellent because it is already above 50 percent. In other words, the selection of variables that affect the dependent variable is exact.

7) Panel model regression analysis in Thailand.Estimation results of the model of the effect of capital structure (DER), asset growth (GRO), managerial ownership (share), number of committees and commissioners with the typical effect estimation method in Thailand can be seen in Table 10. below:

TABLE $\mathrm{X}$

ESTIMATION RESUlts OF THE MODEL OF THE INFLUENCE OF DER, GRO, SHARESON COMPANY PERFORMANCE IN THAILAND.

\begin{tabular}{lrrr}
\hline \hline Variable & Coefficient & Standard error & Probability \\
\hline Constant & 2.239 & 0.814 & 0.009 \\
DER & -0.120 & 0.076 & 0.122 \\
GRO & -0.041 & 0.067 & 0.540 \\
Committee & 1.387 & 0.308 & $0.000^{*}$ \\
Commissioner & 1.452 & 0.234 & $0.000^{*}$ \\
Stock & 1.261 & 0.176 & $0.000^{*}$ \\
\hline R-square & & & 0.868 \\
Adjusted R-square & & & 0.849 \\
F-statistic & & & 44.866 \\
Prob (F-statistic) & & & 0.000 \\
\hline \hline
\end{tabular}

Based on Table 10, it can be written the equation of the EVA dependent variable with independent variables, namely the internal structure (DER), asset growth (GRO), number of committees, number of commissioners, and managerial ownership (shares) as follows:

$$
E V A=2.239-0.120-0.041+1.387+1.452+1.261+e
$$


Based on Table 11 it can be seen that together the independent variables included in this study affect the performance of mining companies in Indonesia. This can be seen from the F-statistical probability of 0.000 . The Adjusted R Square value of this model is 0.849 which means that the variation of the variable of the company's performance (EVA) which can be explained by the independent variable in the study is 84.90 percent, the remaining 15.10 percent is explained by other factors not included in this study. Adjusted $\mathrm{r}$ square value is excellent because it is already above 50 percent. In other words, the selection of variables that affect the dependent variable is exact.

\section{CONCLUSIONS}

The capital structure (DER) does not affect the performance of mining companies in Indonesia, Malaysia, and Thailand.Asset growth (GRO) shows an influence on the performance of mining companies in Indonesia and Malaysia while in Thailand it does not show its influence. The board of commissioners variable shows the effect on the performance of mining companies in Indonesia while Malaysia and Thailand do not show significant influence. The committee council variable shows the influence on the performance of mining companies in Malaysia while in Indonesia and Thailand there is no significant influence. This research recommends some issues. For companies, influential factors can be used as a basis for improving the performance of mining companies. For advanced researchers, it is expected to increase the number of countries in the ASEAN Region and the more extended research period, so that it is expected to get better results. In addition, it is expected to add other research variables that are expected to have more influence on profitability.For investors, the results of this study are expected to be taken into consideration by investors in deciding to invest in the future.

\section{REFERENCES}

[1] T. Donaldson and L. E. Preston, "The stakeholder theory of the corporation: Concepts, evidence, and implications," Acad. Manag. Rev., vol. 20, no. 1, pp. 65-91, 1995.

[2] D. Otley, "Performance management: a framework for management control systems research," Manag. Account. Res., vol. 10, no. 4, pp. 363-382, 1999.

[3] A. S. X. C. G. Council, Principles of good corporate governance and best practice recommendations. Australian Stock Exchange Limited, 2003.

[4] J. P. Charkham, Keeping good company: A study of corporate governance in five countries. Oxford University Press, 1995.

[5] M. Utama, "The Implementation of Good Corporate Governance in Indonesia Company," Simbur Cahaya, vol. 16, no. 44, pp. 2279-2286, 2011.

[6] C. A. Romano, G. A. Tanewski, and K. X. Smyrnios, "Capital structure decision making: A model for family business," J. Bus. Ventur., vol. 16, no. 3, pp. 285-310, 2001.

[7] E. A. Helfert, Techniques of financial analysis: a guide to value creation. Irwin/McGrawHill, 2000.

[8] J. M. Stern, G. B. Stewart III, and D. H. Chew, "The EVA® financial management system," J. Appl. Corp. Financ., vol. 8, no. 2, pp. 32-46, 1995.

[9] W. D. Presutti Jr, "Supply management and e-procurement: creating value added in the supply chain,” Ind. Mark. Manag., vol. 32, no. 3, pp. 219-226, 2003.

[10] E. F. Brigham and J. F. Houston, Fundamentals of financial management. Cengage

International Journal on Advanced Science, Education, and Religion (IJoASER) 
Learning, 2012.

[11] J. M. Wooldridge, Econometric analysis of cross section and panel data. MIT Press, 2010.

[12] A. Bell and K. Jones, "Explaining fixed effects: Random effects modeling of time-series cross-sectional and panel data," Polit. Sci. Res. Methods, vol. 3, no. 1, pp. 133-153, 2015. 